\title{
High amphibian diversity related to unexpected environmental values in a biogeographic transitional area in north-western Mexico
}

\author{
José M. Serrano ${ }^{1}$, César A. Berlanga-Robles², ${ }^{2}$, Arturo Ruiz-Luna² \\ ${ }^{1}$ Universidad Autónoma Metropolitana, Unidad Xochimilco,Departamento El Hombre y su Ambiente, Universidad \\ Autónoma Metropolitana, Unidad Xochimilco, 04960 DF, Mexico \\ ${ }^{2}$ Centro de Investigación en Alimentación y Desarrollo A.C., Coordinación Regional Mazatlán, Av. Sábalo Cerritos \\ s/n, Mazatlán, Sinaloa, Mexico 82100 \\ ${ }^{3}$ E-mail: cesar@ciad.mx
}

Key words: $\alpha$-diversity, $\beta$-diversity, $\gamma$-diversity, distribution maps, nestedness, turnover

\begin{abstract}
Amphibian diversity and distribution patterns in Sinaloa state (north-western Mexico) were assessed from the Global Amphibian Assessment database (GAA-2010). A geographic information system (GIS) was used to evaluate diversity based on distribution maps of 41 species, associated with environmental data. The highest $\alpha$ and $\gamma$-diversities were identified in the south-eastern portion of the state, in mountain zones with a warm sub-humid climate, whereas the greatest $\beta$-diversity (multiplicative formulation) was aggregated in patches in the western portion of the state in mountains with temperate climates. A cluster analysis and Mantel test showed a strong association of Sorensen's dissimilarity (additive formulation of $\beta$-diversity) with climate and soil moisture categories rather than physiographic categories. Additionally, the partition of Sorensen's dissimilarity into its components (turnover and nestedness) showed a gradient of species turnover related to contrasting climate units and a marked pattern of nestedness between the middle mountains and the coastal plain. The results of the study suggest that the highest $\alpha$ and $\beta$-diversity values occur in the middle-humidity range as well in the transitional-climate categories. This pattern is unusual for amphibian distributions because the highest global and regional amphibian diversities are typically related to high humidity values and climate stability (warm and wet most of the year). This particular pattern, occurring in a transitional area, encourages further biological and ecological studies to clarify the status of amphibian populations and support conservation measures.
\end{abstract}

\section{Contents}

Introduction ………………………………………………....... 151

Material and methods .......................................................... 153

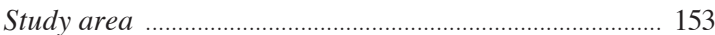

GIS modelling of Sinaloa's amphibian diversity ........... 154

GIS modelling of additive formulation of $\beta$-diversity ... 154

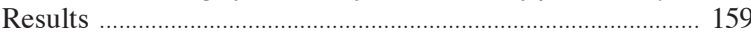

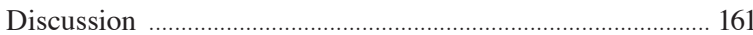

Amphibian diversity in Sinaloa ......................................... 161

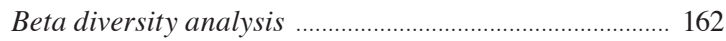

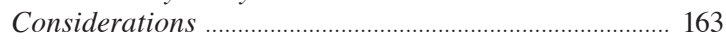

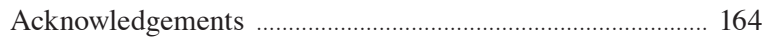

References …………………………………………………..... 164

\section{Introduction}

Among vertebrates, amphibians are the most endangered group worldwide. Nearly one-third of the approximately 6300 known species is threatened and around 170 species are presumably extinct (http://amphibiaweb.org/, accessed Nov. 2013). Since 1980, more than 400 species have moved to a higher risk category on the International Union for Conservation of Nature (IUCN) Red List. By contrast, less than $1 \%$ of the amphibian populations worldwide are increasing. The true magnitude of the threat is unknown because no population data exist for at least 25-30\% of amphibian species and the basic biology of most amphibian species remains uninvestigated (Stuart et al., 2004; Collins and Crump, 2009; Hoffman et al., 2010).

Possible causes of amphibian decline are global warming, harvesting and overexploitation, pollution, exotic species, increased ultraviolet radiation, diseases or the synergistic action of these factors (Stuart et al., 2004; Collins and Crump, 2009; Hof et al., 2011). In recent years chytridiomycosis, a disease distributed worldwide and caused by the aquatic pathogen Batrachochytrium dendrobatidis, was identified as a principal cause of the massive worldwide amphibian decline (Daszak et al., 2003; Seimon et al., 2006; Fisher et al., 2009). Particularly for the American ('New World') amphibians evidence suggests that habitat loss could be the major risk factor (Young et al., 2004). Recently, Hof et al. (2011) have proposed that climate change and 


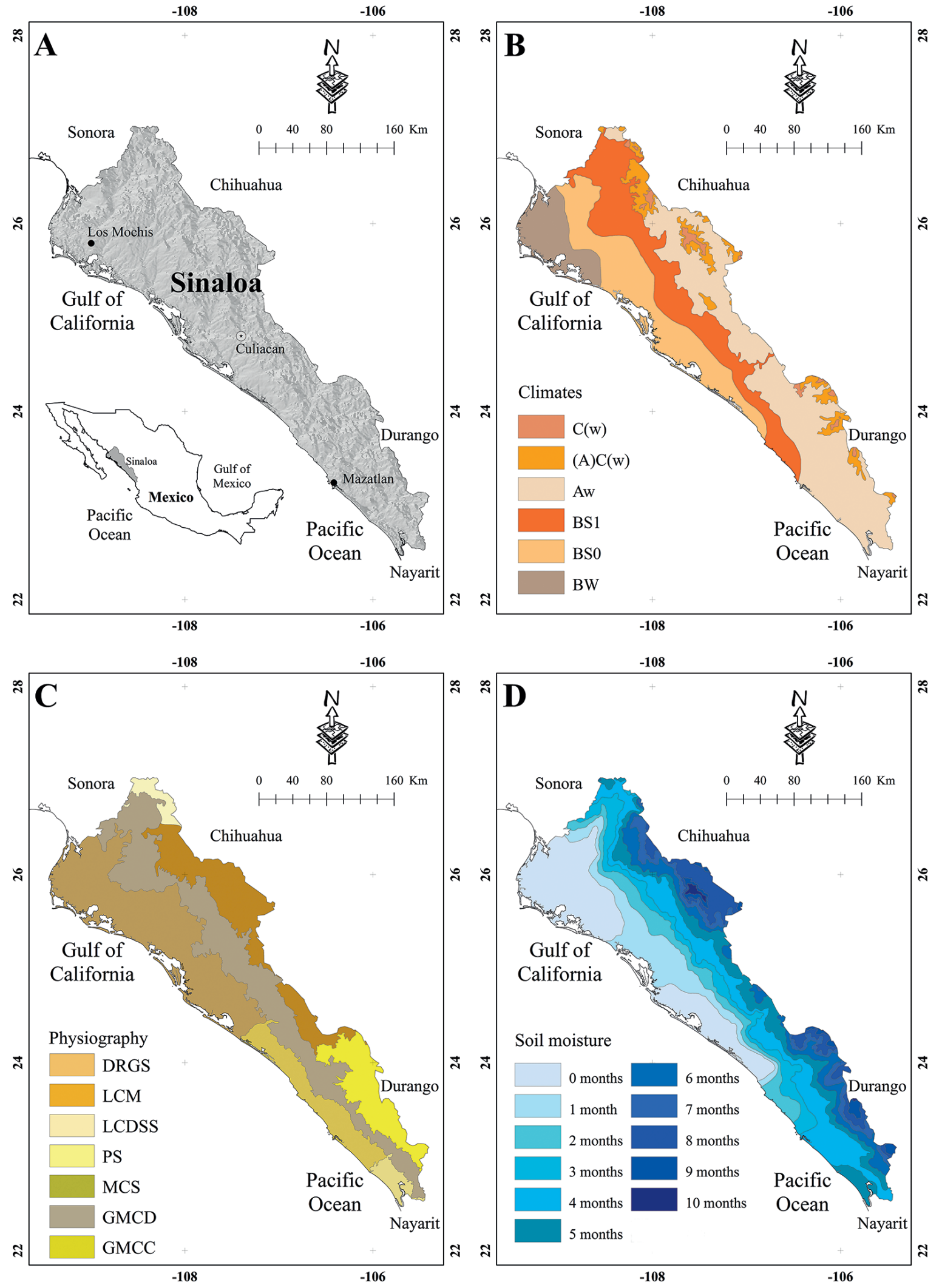


chytridiomycosis are the principal factors threatening American amphibians.

The American continent, including the Caribbean Sea islands, harbours approximately half of the world's amphibian species, but almost $40 \%$ of them are presumed extinct, near extinction or threatened (Young et al., 2004). As other taxa, amphibian species richness increases at latitudes near the Equator (Duellman, 1999; Baselga et al., 2012), but the particular geography and physiography of Mexico have favoured the colonization of species from the Neotropical and Nearctic regions (Campbell, 1999; Pineda and Lobo, 2012). Because of this, Mexico ranks fifth in amphibian diversity at worldwide level, with the greatest number of amphibians (particularly endemic anurans) of any country in North and Central America (Campbell, 1999). Nevertheless, few studies on the population ecology of Mexican amphibians have been published, and the current status of Mexico's amphibian species is uncertain. However, the available information indicates that of the 373 species recorded in Mexico, 228 (> 60\%) are endemic, and 164 (44\%) are included in the IUCN Red List threatened categories as Vulnerable (25), Critically Endangered (74) and Endangered (65) (Ochoa-Ochoa et al., 2009).

Given the limited data availability on Mexican amphibians, GIS applications can be used to integrate the existing distribution data (geographically referenced) with environmental parameters (e.g. climate, land cover and land use, soils, presence/absence of pathogens) to analyse the distribution patterns of species diversity, to relate them to essential habitat needs, to identify potential impacts of habitat loss and global climate change, and to suggest priority areas for conservation (Hayek and McDiramid, 1994; Guisan and Hofer, 2003; Soberon and Nakamura, 2009; Soberon, 2010; UrbinaCardona and Flores-Villela, 2010).

Fig. 1. Study area. A) Sinaloa State is located in north-western Mexico. B) Climates: $\mathrm{C}(\mathrm{w})=$ temperate sub-humid, $(\mathrm{A}) \mathrm{C}(\mathrm{w})=$ tropical semi-warm sub-humid, Aw = warm sub-humid, $\mathrm{BS} 1=$ semi-warm, BS0 = warm and dry and BW = very dry and warm. C) Physiography (physiographic sub-provinces): DRGS, Delta del Río Grande de Santiago = Santiago River Delta, LCM, Llanura Costera de Mazatlán = Mazatlan Coastal Plain, LCDSS, Llanura Costera y Delta de Sonora y Sinaloa = Sonora-Sinaloa Delta and Coastal Plain, PS, Pie de la Sierra = Lower Montane, MCS, Mesetas y Cañadas del Sur = Southern Plateaus and Canyons, GMCD. Gran Meseta y Cañadas Duranguenses = Durango's Great Plateau and Canyons, GMCC, Gran Meseta y Cañadas Chihuahuenses = Chihuahua's Great Plateau and Canyons. D) Soil moisture duration (months).
Additionally, efforts to understand actual distribution and diversity patterns require the use and interpretation of biodiversity measures for which many different methods have been suggested (Halffter, 1998; Baselga, 2010). Estimating species diversity at local and regional level is a basic phase in the information gathering process to assess the importance of landscapes or operationally manageable regions and make it noticeable to environmental authorities (Burgman et al., 2005; Elith and Leathwick, 2009). When data required for the assessment is limited, distribution maps become an alternative source of baseline data for ecology and conservation studies, even at the risk of producing some over- or under-estimation (Ochoa-Ochoa et al., 2009).

Given that spatial patterns of amphibian diversity in Sinaloa (north-western Mexico) are poorly understood, while they are necessary to help decision making for conservation, the aim of the present study is to characterize amphibians diversity in a region considered as remarkable for herpetological studies because of its location in a transitional zone between the temperate region of North America and the tropical region of Central America (Hardy and McDiarmid, 1969).

We propose a methodological approach for assessing the diversity and distributional patterns of amphibian assemblages in areas that have not been explored recently. The study integrates a GIS framework with amphibian distribution data from the Global Amphibian Assessment (GAA-2010) developed by the IUCN. In addition, the analysis includes geographic and environmental information. In view of the quality of the input data, we discuss some limitations of the method and potential over- or underrepresentation in spatial patterns. This study provides a spatial framework for future monitoring and conservation policies and research development, rather than outputs of precise distribution maps or conclusions about the origins of amphibian diversity.

\section{Material and methods}

\section{Study area}

As part of a process to evaluate the Mexican natural capital at national and state-wide scale, we confined the present study to the political boundaries of Sinaloa. This Mexican state is the $18^{\text {th }}$ largest by size, with a surface area $>57,000 \mathrm{~km}^{2}$. Sinaloa leads the nation in food production, primarily because of agriculture and fishing. It is located between $22^{\circ} 31^{\prime}$ and $26^{\circ} 56^{\prime}$ north latitude and 
$105^{\circ} 24^{\prime}$ and $109^{\circ} 27^{\prime}$ west longitude (Fig. 1A). Climate and precipitation patterns vary substantially throughout the state, presenting six climate types (Fig. 1B), from temperate sub-humid $(\mathrm{C}(\mathrm{w}))$ to very dry and warm $(\mathrm{BW})$, according to the Köppen climate classification system (modified by García, 1987). The average rainfall ranges between 100 to $400 \mathrm{~mm}$ in the driest regions and 800 to $1200 \mathrm{~mm}$ in the wettest. The annual mean temperatures range from $14^{\circ}$ to $26^{\circ} \mathrm{C}$ (INEGI, 1995).

Sinaloa includes the physiographic provinces of the Sierra Madre Occidental (SMO), with four sub-provinces, and the Llanura Costera del Pacífico (PCP = Pacific Coastal Plain) with three sub-provinces (Fig. 1C). The SMO consists of a mountainous strip parallel to the coastline, with altitudes ranging from 100 to $2780 \mathrm{~m}$ above sea level (m.a.s.1.). The PCP, at the western part of Sinaloa, is basically dominated by floodplains and complex lagoon systems, estuaries, and bays. The coastal plain is also the region where most of the human population and largest cities are constrained whereas the SMO province generally maintains its ecological integrity (Berlanga-Robles and Ruiz-Luna, 2011). Additionally, soil moisture varies substantially in the state, with extreme conditions in northwest and middle Sinaloa (driest) and in the east (wettest) in the mountains (Fig. 1D).

\section{GIS modelling of Sinaloa's amphibian diversity}

Based on amphibian species distribution data from the GAA-2010 (IUCN, 2010), the distribution patterns of amphibian diversity were identified for the boundaries of Sinaloa. The maps on a scale of 1:1,000,000 consist of polygons drawn by joining points representing known locations along a suitable habitat continuum. The validation of these species distribution maps was performed by herpetology specialists. Polygons were fitted to the Sinaloa's boundaries with a clip function using ArcGIS 9.3. The polygon of Sinaloa used in this step was digitized from the Sinaloa State Chart, scale 1:750,000 (INEGI, 2005). The output was exported to Idrisi Selva (Clark Labs, Clark University), in which the diversity analysis tools available in the Biodiversity Analysis of Land Change Modeler module were used to produce Boolean maps (i.e. presence-absence maps; one for each species) in raster format with a $1 \mathrm{~km}^{2}$ pixel. These maps were used to compute the $\alpha, \beta$ and $\gamma$-diversity values for Sinaloa.

The $\alpha$-diversity was computed by overlapping the species maps to obtain the total number of species in a locality defined by a $1-\mathrm{km}^{2}$ pixel. The $\gamma$-diversity, the richness of species over a region, was calculated by comparing the species composition in each pixel to the corresponding values in a circular zone surrounding it. For the calculation of $\gamma$-diversity, a focal zone with a diameter of $60 \mathrm{~km}$ was moved successively over every pixel. The diameter of focal zones was set to $60 \mathrm{~km}$ to include climate, physiography and soil moisture gradients present throughout the state. The resulting output values were then used to calculate $\beta$-diversity based on a multiplicative formulation $\left(\mathrm{H}_{\beta}=\mathrm{H}_{\gamma} / \mathrm{H}_{\alpha}\right)$, dividing the $\gamma$-diversity by the average $\alpha$-diversity for each region (Eastman, 2012).

\section{GIS modelling of additive formulation of $\beta$-diversity}

Variation in amphibian species composition was analysed with the Sorensen dissimilarity index, an additive formulation of $\beta$-diversity (Baselga, 2010). Maps of climate, physiographic provinces/sub-provinces and soil moisture extracted from the Digital Map of Mexico, scale 1:1,000,000 (INEGI, 2005) were integrated into the GIS thematic vector. In addition, the soil moisture map shows a time gradient representing the months of the year that show detectable water in the soil. These parameters are determinants of amphibian occurrence and, therefore, of amphibian species richness. Data layers were included as generalized representations of the environmental factors that directly and indirectly influence amphibian species distributions (Currie, 1991; Duellman, 1988; 1999; Allen et al., 2002; Baselga et al., 2012; Munguía, 2012).

The three thematic maps (Fig. 1B-D) were separately overlaid, using an intersect function, with the map of the species distribution to produce species presence/absence matrices between categories for each environmental factor. From these results, the $\beta$-diversity was additively estimated with the Sorensen dissimilarity index (Eq. 1):

$$
\beta_{\text {Sor }}=\frac{(b+c)}{(2 a+b+c)}
$$

where $a$ is the number of species coincidences in two categories, $b$ is the number of species present in the first category but not in the second and $c$ is the number of species present in the second category but not in the first (Baselga, 2010).

The dissimilarity values were then ordered with a Q-type cluster analysis, which classifies the environmental categories as a function of the species distribution. The classification was performed with the Weighted Pair Group Method using the arithmetic averages algorithm (WPGMA) with the Sorensen index values as the distance measure (James and McCulloch, 1990). 
Table 1. Species and threat status of amphibians of Sinaloa, Mexico. NOM-059-2010 = Official Mexican Norm for environmental and species protection, $\mathrm{LC}=$ Least Concern, $\mathrm{EN}=$ Endangered, $\mathrm{VU}=$ Vulnerable, $\mathrm{DD}=$ Data deficient, $\mathrm{ND}=\mathrm{No}$ data available, $\mathrm{Pr}=\mathrm{Least}$ Concern, $\mathrm{A}=$ Threatened, 1 = forest exploitation, $2=$ agriculture, $3=$ pollution, $4=$ anthropogenic development, $5=$ climate change, 6 $=$ people, $7=$ exotic species.

\begin{tabular}{llllll}
\hline Family/Species & Distribution & Red List & Population & $\begin{array}{l}\text { Main } \\
\text { threat }\end{array}$ & $\begin{array}{l}\text { NOM-059- } \\
\text { trend }\end{array}$
\end{tabular}

Ambystomatidae

Ambystoma rosaceum Taylor, 1941

A. velasci (Dugès, 1888)

Plethodontidae

Pseudoeurycea bellii (Gray, 1850)

Bufonidae

Anaxyrus cognatus (Say, 1822)

A. kelloggi (Taylor, 1938)

A. mexicanus (Brocchi, 1879)

A. punctatus (Baird and Girard, 1852)

Incilus alvarius (Girard, 1859)

I. marmoreus (Wiegmann, 1833)

I. mazatlanensis (Taylor, 1940)

I. occidentalis (Camerano, 1879)

Rhinella marina (Linnaeus, 1758)

Craugastoridae

Craugastor augusti (Dugès, 1879)

C. hobartsmithi (Taylor, 1937)

C. occidentalis (Taylor, 1941)

C. vocalis (Taylor, 1940)

Eleutherodactylidae

Eleutherodactylus interorbitalis (Langebartel and Shannon, 1956)

E. nitidus (Peters, 1870)

E. saxatilis (Webb, 1962)

E. teretistes (Duellman, 1958)

Hylidae

Agalychnis dacnicolor (Cope, 1864)

Diaglena spatulata (Günther, 1882)

Exerodonta smaragdina (Taylor, 1940)

Hyla arenicolor Cope, 1866

H. eximia Baird, 1854

H. wrightorum Taylor, 1939

Plectrohyla bistincta (Cope, 1877)

Smilisca baudinii (Duméril and Bibron, 1841)

S. fodiens (Boulenger, 1882)

Tlalocohyla smithii (Boulenger, 1902)

Trachycephalus typhonius (Linnaeus, 1758)

Leptodactylidae

Leptodactylus melanonotus (Hallowell, 1861)

Mycrohylidae

Gastrophryne olivacea (Halloewll, 1856)

Hypopachus ustus (Cope, 1866)

H. variolosus (Cope, 1866)

Ranidae

Lithobates catesbeianus (Shaw, 1802)

L. forreri (Boulenger, 1883)

L. magnaocularis (Frost and Bagnara, 1974)

L. pustulosus (Boulenger, 1883)

L. tarahumarae (Boulenger, 1917)

Scaphiopodidae

Scaphiopus couchii Baird, 1854
Endemic

LC

Endemic

VU

Endemic

Endemic

Endemic

Endemic

Endemic

Endemic

Endemic

LC

EN

DD

LC

Endemic

Endemic

Endemic

Endemic

DD

LC

EN

DD

LC
LC

Endemic

$\mathrm{LC}$
$\mathrm{LC}$

Endemic

$$
\text { LC }
$$

Endemic

LC

LC

LC

LC

LC

Endemic

LC

LC

LC

LC

LC

LC

Endemic

LC

LC

Endemic

LC

VU

LC
ND

Declining

Declining

Stable

Declining

Stable

Stable

Stable

Stable

Stable

Increasing

Stable

Declining

ND

Declining

$1,2,4$

SD

$1,2,4$

ND

Declining

Declining

ND

Declining

ND

Stable

Stable

Stable

Stable

Declining

Stable

Stable

Declining 1, 2, 4

Stable

Stable

Stable

Stable

Stable

Stable

ND

Stable

Declining

2

$3,6,7$

$\operatorname{Pr}$

Pr

A

4

3

1

2

2

Pr

$1,2,4$

5

1, 2, $4 \quad \operatorname{Pr}$

1

Pr

2

$1,2,4$

3

5

4

Pr

$\operatorname{Pr}$

Stable 

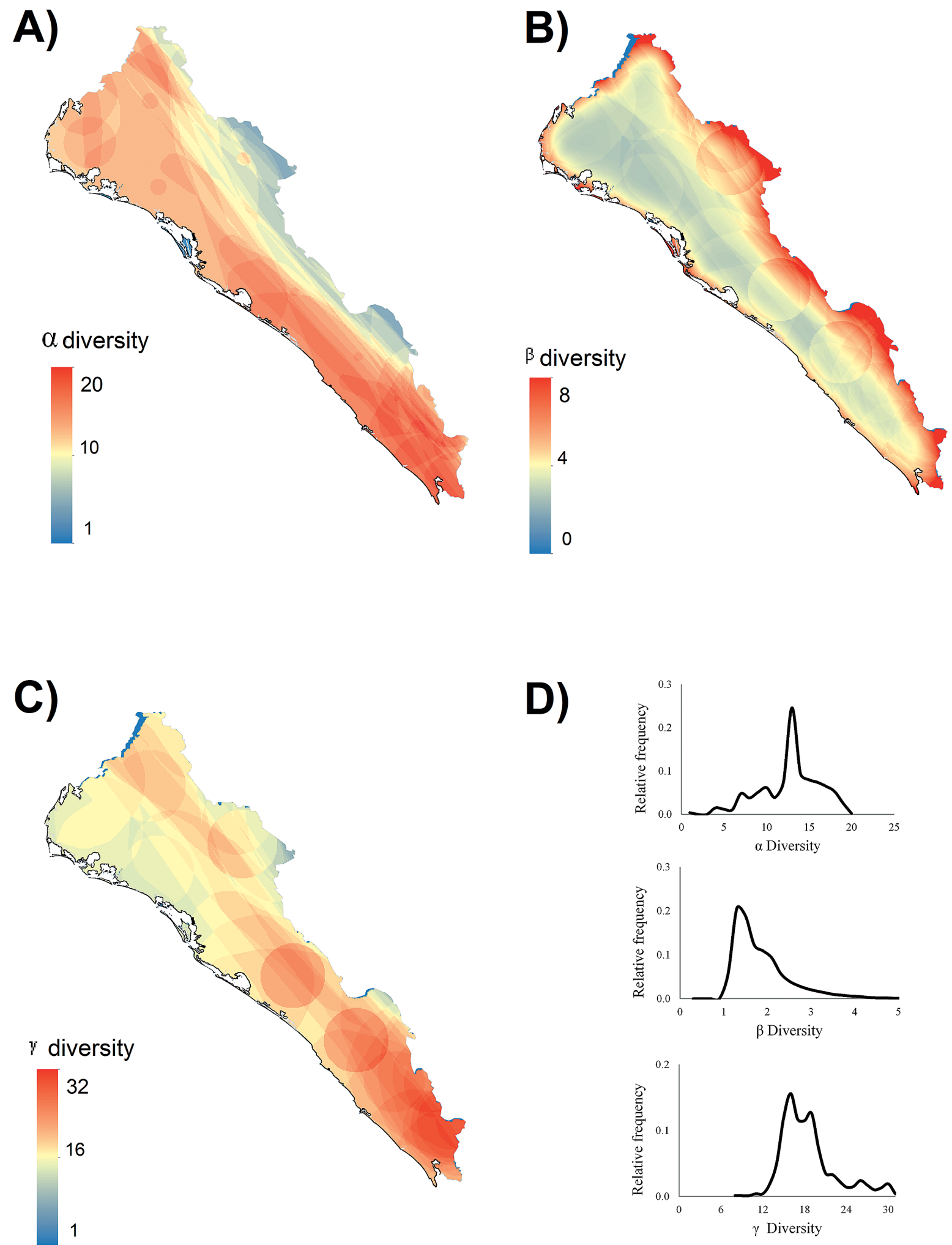

D)
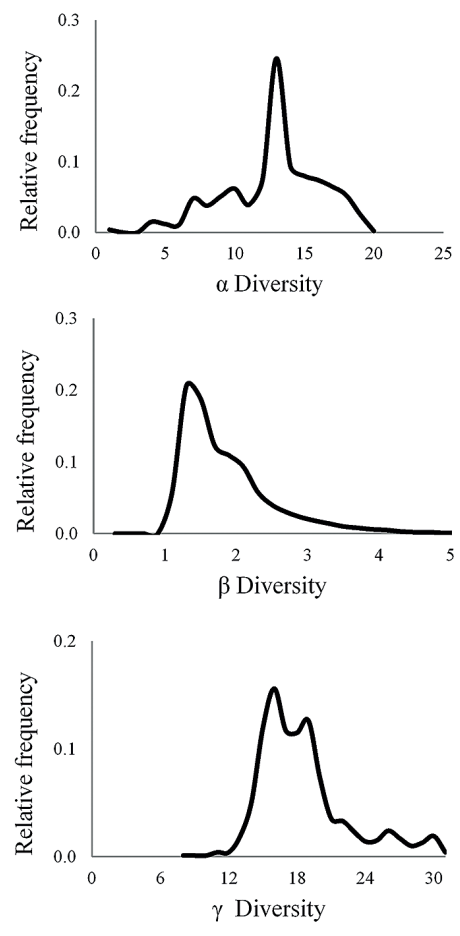

Fig. 2. Amphibian diversity indexes for Sinaloa. A) $\alpha$-diversity, B) multiplicative formulation of $\beta$-diversity and C) $\gamma$-diversity. The graphs show the frequency distribution for each index. 
Table 2. Total and relative extent (ha and \%) and diversity index values at pixel (average) and category level for amphibian fauna in Sinaloa, Mexico, as a function of environmental factors. At the pixel level, the diversity index is the average of the pixel values for each category. At the category level, $\beta=\gamma /, \gamma=$ number of species by category.

\begin{tabular}{|c|c|c|c|c|c|c|c|c|}
\hline \multirow[b]{3}{*}{ Factor/Category } & \multirow[b]{3}{*}{ Code } & \multirow[b]{2}{*}{ Area } & \multicolumn{6}{|c|}{ Diversity } \\
\hline & & & \multicolumn{4}{|c|}{ Pixel level } & \multicolumn{2}{|c|}{ Category level } \\
\hline & & ha & $\%$ & $\bar{\alpha}$ & $\bar{\beta}$ & $\bar{\gamma}$ & $\beta$ & $\gamma$ \\
\hline Sinaloa & & 5412917 & & 12 & 1.9 & 17.6 & 3.4 & 41 \\
\hline \multicolumn{9}{|l|}{ A) Climate } \\
\hline Temperate sub-humid & $\mathrm{C}(\mathrm{w})$ & 803 & 1.5 & 8.6 & 2.6 & 16.1 & 3.2 & 28 \\
\hline Tropical semi-warm sub-humid & $(\mathrm{A}) \mathrm{C}(\mathrm{w})$ & 3735 & 6.9 & 8.8 & 2.6 & 16.6 & 3.4 & 32 \\
\hline Warm sub-humid & Aw & 20709 & 38.3 & 12.1 & 2.2 & 20.3 & 3.1 & 39 \\
\hline Semi-warm & BS1 & 13076 & 24.2 & 12.4 & 1.5 & 17 & 1.9 & 26 \\
\hline Warm and dry & BS0 & 11152 & 20.6 & 12.7 & 1.5 & 15.2 & 1.5 & 20 \\
\hline Very dry and warm & $\mathrm{Bw}$ & 4654 & 8.6 & 12 & 1.6 & 14 & 1.2 & 16 \\
\hline \multicolumn{9}{|l|}{ B) Physiography } \\
\hline Delta del Río Grande de Santiago & DRGS & 1179 & 2.2 & 17.3 & 2.2 & 22.9 & 1.2 & 21 \\
\hline Llanura Costera de Mazatlán & LCM & 4940 & 9.1 & 15.8 & 1.7 & 19.3 & 1.4 & 23 \\
\hline Llanura Costera Delta de Sonora Sinaloa & LCDSS & 16305 & 30.1 & 12.3 & 1.5 & 14.9 & 1.5 & 20 \\
\hline Pie de la Sierra & PS & 16539 & 30.6 & 12.4 & 1.7 & 18.8 & 2.6 & 34 \\
\hline Mesetas and Cañadas del Sur & MCS & 5428 & 10 & 12.1 & 2.5 & 22.9 & 2.4 & 30 \\
\hline Gran Meseta y Cañadas Duranguenses & GMCD & 8622 & 15.9 & 8.3 & 2.4 & 15.9 & 3.2 & 27 \\
\hline Gran Meseta y Cañadas Chihuahuenses & GMCC & 1116 & 2.1 & 8.3 & 2.4 & 14 & 1.8 & 18 \\
\hline \multicolumn{9}{|l|}{ C) Soil moisture duration } \\
\hline 0 months & $0 \mathrm{mo}$ & 12263 & 22.7 & 12.8 & 1.5 & 15.1 & 1.4 & 20 \\
\hline 1 month & $1 \mathrm{mo}$ & 6365 & 11.8 & 12.6 & 1.4 & 15.5 & 1.7 & 23 \\
\hline 2 months & $2 \mathrm{mo}$ & 4537 & 8.4 & 13.1 & 1.5 & 17.1 & 1.7 & 24 \\
\hline 3 months & $3 \mathrm{mo}$ & 4742 & 8.8 & 12.9 & 1.6 & 18.3 & 1.9 & 26 \\
\hline 4 months & $4 \mathrm{mo}$ & 9109 & 16.8 & 13 & 1.8 & 20.2 & 2.3 & 32 \\
\hline 5 months & $5 \mathrm{mo}$ & 6018 & 11.1 & 11.7 & 2.2 & 19.8 & 2.8 & 34 \\
\hline 6 months & $6 \mathrm{mo}$ & 4070 & 7.5 & 11 & 2.3 & 20.2 & 2.8 & 32 \\
\hline 7 months & $7 \mathrm{mo}$ & 2380 & 4.4 & 10 & 2.5 & 18.8 & 2.8 & 29 \\
\hline 8 months & $8 \mathrm{mo}$ & 3582 & 6.6 & 7.6 & 2.9 & 15.8 & 3.7 & 29 \\
\hline 9 months & $9 \mathrm{mo}$ & 893 & 1.6 & 8.9 & 3.2 & 17.4 & 2.8 & 27 \\
\hline 10 months & $10 \mathrm{mo}$ & 171 & 0.3 & 8.7 & 2.1 & 15.1 & 4.2 & 18 \\
\hline
\end{tabular}

The cluster analyses were complemented with a Mantel test to evaluate the association between the Sorensen dissimilarity and the environmental distance matrices (Manly, 1986; Legendre and Fortin, 1989, 2010; Sokal and Rohlf, 2001). The environmental distance matrices were designed by constructing bi-dimensional spaces with essential quantitative variables, further incorporating new environmental information layers: Bioclimatic variables from WorldClim, namely, Annual mean temperature (BIO1) and Annual precipitation (BIO12), with $1 \mathrm{~km}$ resolution; a Digital Elevation Model (AsterDEM) with $30 \mathrm{~m}$ resolution; and the averages of Land Surface Temperature and Normalized
Differential Vegetation Index (NDVI) estimated from 2002 to 2012 imagery of the MODIS monthly composites Land Surface Temperature and Emissivity (MOD11C3) and Vegetation Index (MOD13A3) with 0.5 degree and $1 \mathrm{~km}$ resolution, respectively.

The bi-dimensional climate space included the variables $\mathrm{BIO1}$ and $\mathrm{BIO12}$, whereas the physiographic space was formed with the altitude and terrain slope extracted from the Aster DEM. The soil moisture space was formed with the land surface temperature and values from the NDVI, as the triangle method uses these two variables to estimate regional soil moisture status (Carlson, 2007). The categories of different 
environmental factors were located in their respective bi-dimensional spaces according to the mean values of each variable. Mean values were obtained with the Idrisi-Selva Extract module, rasterizing polygons to fit them to the spatial resolution for each variable: climate $(1 \mathrm{~km})$, physiography $(30 \mathrm{~m})$, and soil moisture $\left(0.5^{\circ}\right.$ and $1 \mathrm{~km}$ ). A symmetrical distance matrix was then produced using the Euclidean distance measure, and a Mantel test was performed with 1000 iterations, using the Pearson coefficient as correlation measure. The cluster analysis and the Mantel test were performed with XLSTAT 2013.3.02.

Additionally, the contribution of species nestedness (the biota of a specific site as a subset of the biota from another site) and species turnover (the change in species composition from one place to other) to the $\beta$-diversity represented by the Sorensen dissimilarity index was calculated. As in Baselga (2010), the dissimilarity resulting from nestedness ( $\beta$ nes) is defined in Eq. 2:

$\beta_{\text {nes }}=\beta_{\text {Sor }}-\beta_{\text {Sim }}=\frac{b+c}{2 a+b+c}-\frac{\min (b, c)}{a+\min (b, c)}=\left(\frac{\max (b, c)}{2 a+\min (b, c)+\max (b, c)}\right)\left(\frac{a}{a+\min (b, c)}\right)$

where $\beta_{\text {Sor }}$ is the total Sorensen dissimilarity and $\beta_{\text {Sim }}$ is the Simpson dissimilarity resulting from species turnover. It follows from this equation that $\beta_{\text {Sor }}=\beta_{\text {Sim }}$ $+\beta_{\text {nes }}$. If both locations (categories in the present case) have the same number of species $(b=c)$, then $\beta_{\text {sor }}=$ $\beta_{\text {Sim }}$ and $\beta_{\text {nes }}=0$. In this case, any dissimilarity between two categories having the same number of species is produced entirely by spatial turnover (Baselga, 2010).
A

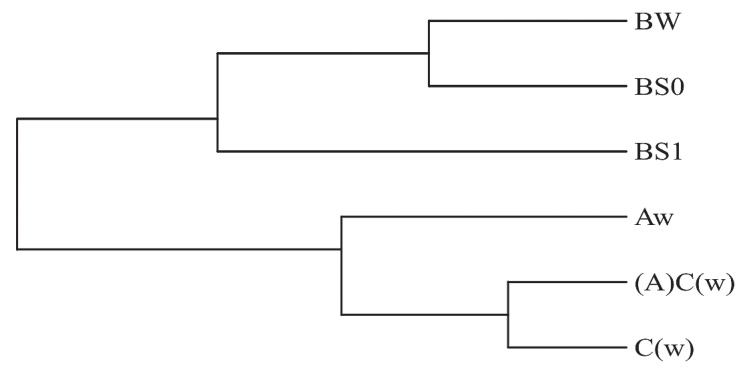

B

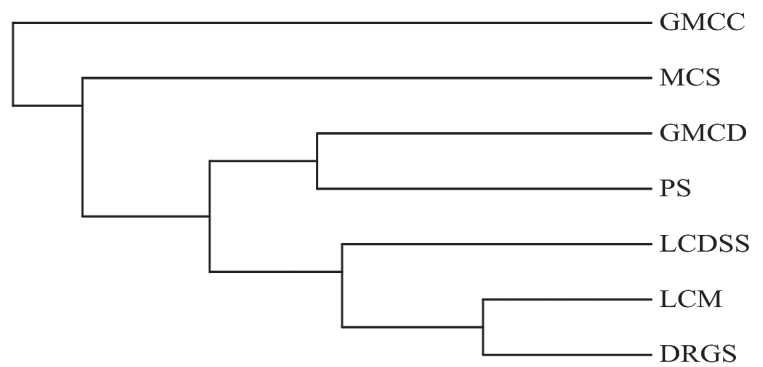

C

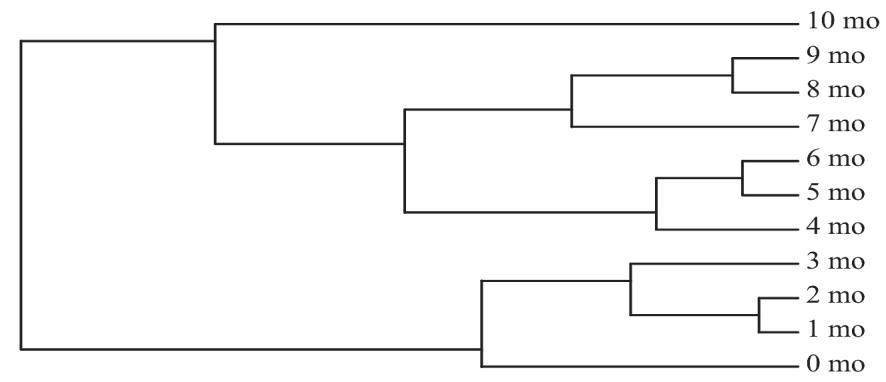

Fig. 3. Q-dendrograms for the clustering (WPGMA) of the Sorensen dissimilitude index $\left(\beta_{\text {Sor }}\right)$ relative to the categories of three environmental factors. A) physiographic, B) climate and C) soil moisture. 


\section{Results}

From the Global Amphibian Assessment database (GAA-2010), forty-one amphibian species were identified for Sinaloa: three salamanders (Caudata: Ambystomatidae and Plethodontidae) and 38 frogs and toads (Anura: Bufonidae, Craugastoridae, Eleutherodactylidae, Hylidae, Leptodactylidae, Microhylidae, Ranidae and Scaphiopodidae). Almost half (20) of the amphibian species in Sinaloa, are endemic to Mexico (Table 1).

According to the IUCN Red List, $80 \%$ of the identified species is classified in the Least Concern category, and five species are in a risk category (Near threatened (1), Vulnerable (2), Endangered (2)). For three species, the available data are not sufficient to evaluate their population status (IUCN 2011). At the local level, over 25\% (11) of the species are included in the Mexican regulations for threatened species (NOM-059-SEMARNAT-2010), but most of them are classified as species of low concern and only one, the endemic Pseudoeurycea bellii, is classified as threatened.

Amphibians were recorded throughout the study area, with at least one species per pixel and a mean $\alpha$-diversity value of 12.8 species (std. dev. 3.5 species). The pixels with higher amphibian species richness $(\alpha$-diversity) were situated in south eastern Sinaloa, following a continuum of 18 to 20 species patches. In contrast, the areas with the lowest species richness (1 species) were located on the sandy barriers of coastal lagoons and, additionally, in mountainous localities of the physiographic sub-provinces MCS and GMCD (Fig. 2A).

The south-eastern portion of the state showed the highest value at the regional level ( $\gamma$-diversity) with 28 to 31 species, whereas the lowest values were found in a region of approximately $250 \mathrm{~km}^{2}$ in the physiographic sub-province GMCD (Fig. 2C). The mean value for this index was 18.5 (std. dev. 3.9 species). For the distribution of amphibians in the state, the values of $\beta$-diversity, calculated as the ratio between $\gamma$-diversity and the mean of $\alpha$-diversity, were greater in patches in the western portion of the state (Fig. 2B), ranging from 4.0 to 7.4 , with an overall average of 1.9 (std. dev. 0.7). There are two circular artefacts in the map of $\gamma$-diversity which correspond to regions (focal zones with a diameter of $60 \mathrm{~km}$ ) with relative high values of regional biodiversity (20 to 25 species). These circular regions are also in the map of $\beta$-diversity, with values from 1.7 to 2.6. The distributions of relative frequencies for all the biodiversity indices are shown in figure 2D.
In terms of the environmental factors analysed, only six of the 41 species were identified for all climates and physiographic and soil moisture categories (Anaxyrus punctatus, Craugastor vocalis, Smilisca baudinii, Agalychnis dacnicolor, Lithobates magnaocularis and Scaphiopus couchii). The species showing most specific environmental requirements was Eleutherodactylus teretistes, found in an $(\mathrm{A}) \mathrm{C}(\mathrm{w})$ climate in the subprovince MCS in areas having soil moisture for at least 5 months. L. catesbeianus also showed specific requirements. It was distributed only in BS0 and BW climates in the sub-provinces LCDSS and PS. Finally, the salamander Ambystoma velasci was also found in restricted areas with $(\mathrm{A}) \mathrm{C}(\mathrm{w})$ and $(\mathrm{Aw})$ climates in the subprovince MCS, with 5 to 6 months of soil moisture.

The region with Aw climate (warm sub-humid) was suitable for all but two species. Moreover, this climate type is prevalent in Sinaloa, covering $38 \%$ of the surface (Table 2). Eleven species were recorded in all climate types. By contrast, the $(\mathrm{A}) \mathrm{C}(\mathrm{w})$ climate only harboured the species Incilius marmoreus, E. teretistes and Trachycephalus typhonius. Although the pixels with the highest $\alpha$-diversity values were located in zones with Aw climate, the highest averages of this index were calculated for the BS0 and BS1 climates. The multiplicative formulation for $\beta$-diversity reached its maximum average values for the $\mathrm{C}(\mathrm{w})$ and $(\mathrm{A}) \mathrm{C}(\mathrm{w})$ climates. The maximum Sorensen dissimilarity value occurred between the BW and C(w) climates, representing the most contrasting categories in terms of their annual mean temperature and annual precipitation, with $18.2^{\circ} \mathrm{C}$ and $1444 \mathrm{~mm}$ for the first and $24.3^{\circ} \mathrm{C}$ and $327 \mathrm{~mm}$ for the second (Euclidean distance $=817.3$ ). The minimum Sorensen dissimilarity occurred between the $\mathrm{C}(\mathrm{w})$ and (A) $\mathrm{C}(\mathrm{w})$ climates, but the lowest Euclidean distance value was obtained between the $\mathrm{Aw}$ and $(\mathrm{A}) \mathrm{C}(\mathrm{w})$ climates. The classification of dissimilarity values produced two clusters reflecting the geographic distribution of amphibians in sub-humid and dry climates (Fig. 3A). The Mantel test showed a significant association between the Sorensen dissimilarity and the Euclidean distance matrix (temperature/precipitation), with a Pearson correlation coefficient of $\mathrm{r}=0.98(\mathrm{P}<0.0001)$.

In terms of the physiographic features, 12 species were present in all sub-provinces, whereas seven species were found only in one sub-province. The sub-province DRGS in the coastal plain showed the highest average value for $\alpha$-diversity. PS and MCS, both sub-provinces in the SMO, showed the greatest number of species and and the highest average $\gamma$-diversity, respectively. Also in the SMO, the sub-provinces GMCS, GMCD and 

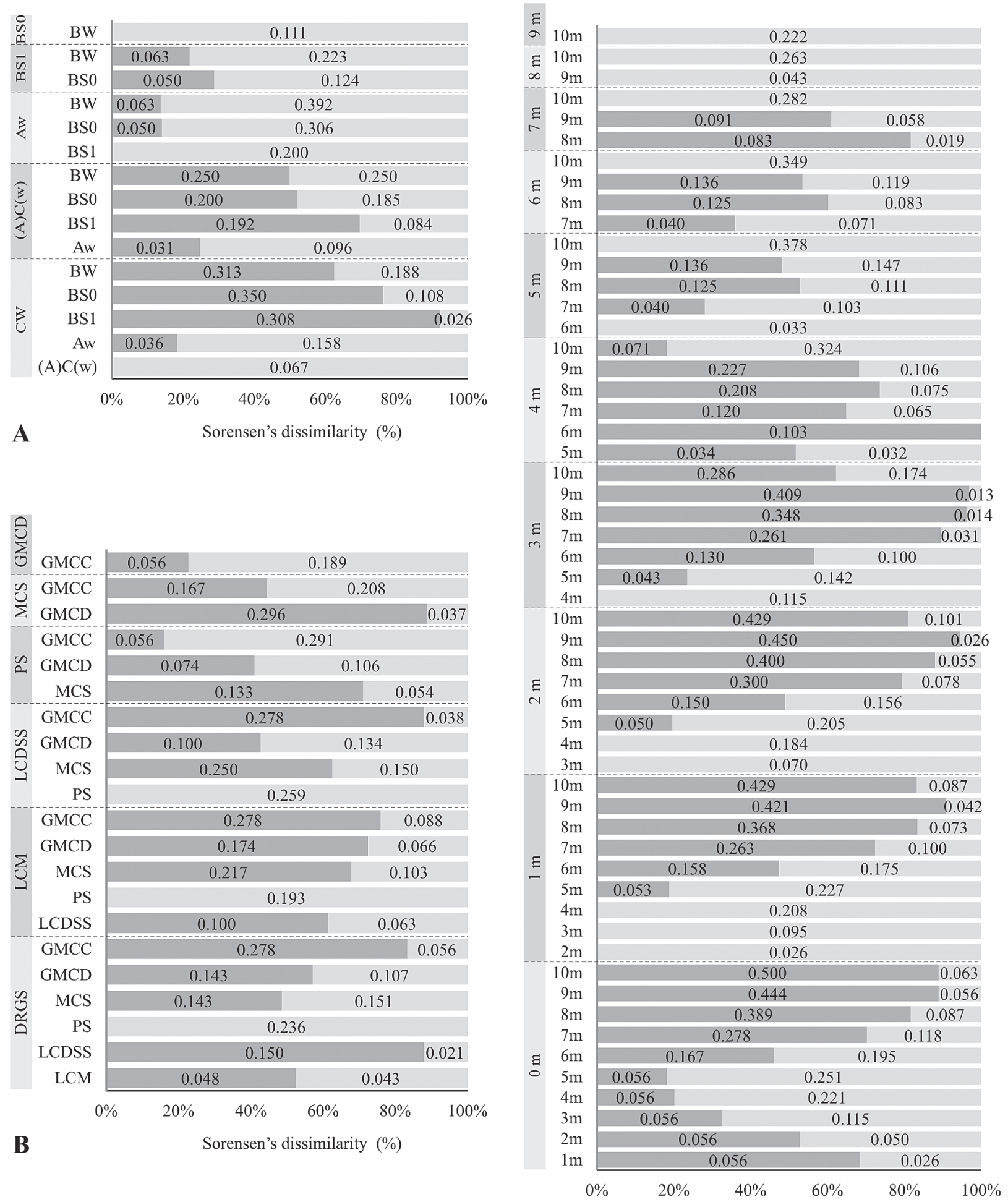

\section{Turnover Nestedness}

C

Sorensen's dissimilarity (\%)

Fig. 4. $\beta$-diversity $\left(\beta_{\text {Sor }}\right)$ partition into its components of turnover $\left(\beta_{\text {Sim }}\right)$ and nestedness $\left(\beta_{\text {Nes }}\right)$ for three environmental factors. A) physiographic, B) climate and C) soil moisture. Values in bars are for $\beta_{\text {Sim }}$ (dark grey) and $\beta_{\text {Nes }}$ (light grey). 
GMCC, had similar average values for the multiplicative formulation of $\beta$-diversity, but GMCD reported the highest value of this index at the category level (Table 2). The cluster analysis based on the Sorensen dissimilarity among physiographic sub-provinces produced two groups. The first group, with the lowest dissimilarities, included the three sub-provinces of the LCP province, characterized by low altitudes and gradual slopes. The sub-provinces PS and GMCD, in the next position on the altitudinal gradient, formed a second group, whereas the northern and southern sub-provinces, GMCC and MCS, remained independent (Fig. 3B). The mountain sub-provinces MCS, GMCD and GMCC showed substantial variation in their species composition despite their similarities in altitude and slope, as reflected by the Mantel test, with an $\mathrm{r}$ value of 0.38 (P $=0.095$ ) between the Sorensen dissimilarity matrix and the physiographic distance matrix.

Soil moisture in Sinaloa is present from 0 to 3 months for most of the state, with 10 months as the maximum value recorded. Approximately $25 \%$ of the species (11) were distributed in all the soil moisture categories, but only Hypopachus variolosus was found in the 0 month category. The highest $\alpha$-diversity average was recorded in areas where soil moisture is present from 2 to 4 months, with 13 species. At the regional level, the greatest number of species was found within the 5 month category, and the greatest average $\gamma$-diversity was found for the category with 4 to 6 months of soil moisture. The highest average value of the multiplicative formulation of $\beta$-diversity was found for the wet areas with 9 months of soil moisture, and the highest estimated value was found for the 10 month category (Table 2). As a result of the classification process, three clusters were obtained at $22 \%$ dissimilarity, separating species with affinities to dry environments (0-3 months) from those with affinities to wet environments (4-9 months) and from an isolated element corresponding to those species found in association with the wettest areas (10 months of soil moisture), as shown in figure 3C. Data from MODIS (2002 to 2012) used to produce the soil moisture bi-dimensional space represent current conditions at Sinaloa state, however, they adequately reflected the historic expected pattern:, where duration of soil moisture (months) is directly related to the NDVI and inversely related to the land surface temperature ( $\mathrm{r}$ $=0.96(\mathrm{P}<0.0001)$ and $\mathrm{r}=-0.94(\mathrm{P}<0.001)$, respectively). The greatest Sorensen dissimilarity corresponded to categories of 0 months and 10 months, however, the greatest Euclidian distance value was found between the categories of 2 months and 10 months. The correla- tion between the Sorensen dissimilarity matrix and the Euclidean distance matrix (NDVI/Land surface temperature) was $0.865(\mathrm{P}<0.0001)$.

The partitioning of Sorensen's dissimilarity $\left(\beta_{\text {Sor }}\right)$ into its components of turnover and nestedness showed that climate acts as a driver to nest species from similar climates, as previously observed when contrasting subhumid temperate and semi-dry climates (Fig. 3A). Between these two groups, however, the dissimilarity was due primarily to species turnover (Fig. 4A).

Regarding physiography, the analysis showed that PS had a tendency to nest with other sub-provinces except for MCS. The variation in species composition involving PS and the sub-provinces of LCP was due entirely to nestedness, but the variation among LCP sub-provinces was associated primarily with species turnover (Fig. 4B). An analogous process was observed with soil moisture, where certain arrangements of categories (i.e. 3 months vs. 4 months, 8 months vs. 9 and 10 months, and 9 months vs. 10 months) had the same number of species, due to dissimilarities among the categories involving species nestedness. In general, 13 of the 55 dissimilarities calculated among these categories were entirely due to species nestedness. In contrast, the turnover was higher than $50 \%$ in 29 comparisons, and the dissimilarity was (almost) entirely due to species turnover between the categories 1 and 9,2 and 9, 3 and 8,3 and 9, and 4 and 6 months of soil moisture. This disparity reflects the higher dissimilarity between the areas of low and intermediate soil moisture in contrast to those of the greatest soil moisture located in the highlands of Sinaloa (Fig. 4C).

\section{Discussion}

\section{Amphibian diversity in Sinaloa}

We modelled $\alpha, \beta$, and $\gamma$-diversities of 41 amphibian species inhabiting Sinaloa state (Mexico) based on IUCN data. The majority of the species (54\%) is endemic to Mexico and the remainder is shared with North America $(28 \%)$ and Central and South America (18\%). Our approach involved the matching of distribution maps with current environmental categories (climate, physiographic and soil moisture), adding details to results of previous studies on the herpetofauna of the region (Hardy and McDiarmid, 1969; Webb, 1984; García, 2006).

Present findings suggest that Sinaloa has high amphibian species richness considering the size of the state, which represents less than $3 \%$ of the country. It is also 
remarkable that the highest amphibian diversity is concentrated in regions with unusual environmental conditions when compared with known global and regional diversity patterns for amphibian distribution. Accordingly, the region represents an important transitional area between the Neotropics and the Nearctic for amphibian distributions.

Results could be biased due to differential sampling effort, considering that southern and northern areas of Sinaloa were sampled to some extent during the 1960s and 1970s (Hardy and McDiarmid, 1969; McDiarmid et al., 1976; Webb, 1984), with limited surveying after this period. It is probable that for undisturbed sites of the SMO, the number of recorded species could increase due to the regional conditions with high humidity and vegetation gradients in the foothills of the mountains produced by the contrasting seasonal temperature and precipitation patterns (McDiarmid et al., 1976; Webb, 1984; Campbell, 1999).

The highest values of $\alpha$-diversity were found in the south-eastern portion of the state, in mountain zones with warm sub-humid climate, while the coastal plain and by warm and dry climates had the lowest $\beta$-diversity and the number of species and the average $\gamma$-diversity were correlated with the climate and soil moisture categories but not with the physiography categories. In most cases, the areas with the highest $\alpha, \beta$ and $\gamma$-diversity values did not correspond to the areas with stable climate and humidity. Such stable conditions promote high amphibian diversity at regional and global scales (Duellman, 1988; Currie, 1991; Duellman, 1999; Duellman and Thomas, 1996; Allen et al., 2002; Baselga et al., 2012).

The diversity patterns associated with warm and wet conditions have been explained as the result of the metabolic potential that drives and sustains the richness of ectotherms, endotherms and plants (Currie, 1991; Allen et al., 2002). Our analysis indicates that amphibian species in Sinaloa display a high tolerance to short cycles of humidity and prolonged drought conditions. This type of ecological tolerance is not yet understood. As suggested by Williams (1996), Araujo (2002) and Spector (2002), biogeographic transition zones usually represent intersections with high species richness. At regional and global scale, the areas with highest amphibian richness are in environments with high humidity or precipitation (Currie, 1991; Duellman, 1999; Allen et al., 2002; Baselga et al., 2012). However, this pattern was not found in Sinaloa state, where most amphibians inhabit areas where moisture is at intermediate levels and relatively stable or semi-dry climates dominate along the year. These patterns could be a consequence of the convergence of Nearctic, Neotropical and transitional species (Morrone, 2005), or a result of the environmental shelter provided by the SMO slopes during the last interglacial (McDiarmid et al., 1976) that could be reflected by the highest amphibian turnover being found in mountain areas (Baselga et al., 2012).

The presence of northern species of the families Bufonidae and Ranidae, and the strong representation of the family Hylidae in the south (Serrano, 2006), could explain the contrasting $\alpha$ and $\gamma$-diversity values for the northern and southern portions of the state. Many species of Hylidae are endemic to Mexico, and the origin of the family is Mesoamerican or transitional (Savage, 1982; Morrone, 2005). Hence, the pattern of dissimilarity observed between the climate and soil moisture categories apparently reflects the synergistic effects of environmental barriers.

\section{Beta diversity analysis}

As expected, the greatest dissimilarity was found between dry and wet climates and categories with intermediate values of soil moisture seasonality, decreasing toward extreme values (Kohlmann and Wilkinson, 2003). These results are consistent with the boundaries between northern assemblages characterized by species of Bufonidae and Ranidae (affinity to drought) and southern assemblages formed primarily by species of Hylidae and Ranidae (affinity to moisture). Moreover, the biogeographic transitional character of the study area is shown by species of the families Eleutherodactylidae, Ranidae and Hylidae (affinity to droughtmoisture transition).

The species dissimilarity phenomenon observed in the study area is expressed as a gradual west-east pattern, not associated with the topography, but with a wider regional extent and the geological and environmental conditions of the SMO, which have acted as biogeographic frontier for amphibians and other taxa (Morrone, 2005). This pattern produced a strong nestedness starting at the PS sub-province, spreading to both east and west, creating a transitional border between the coastal plain and SMO amphibians. However, this effect could be a consequence of the arbitrary delimitation of the study area, instead of natural segregation processes.

Besides the spatial considerations, the analysis of $\beta$-diversity showed a species-nestedness gradient within similar climates and physiographic sub-provinces, between provinces and between similar soil moisture 
categories. These results allowed a clear differentiation between species inhabiting sub-humid climates and those living in dry climates. This pattern differentiates the semi-dry climate (BS1) areas, which may play a transitional role for amphibians occurring in both climates (Casas, 1982), and it coincides with the boundaries of the Sonora (Nearctic origin) and Mexican Pacific Coast (Neotropical origin) biogeographical provinces identified by Morrone (2005).

The distribution of amphibian $\beta$-diversity also displays species nesting and turnover patterns if extreme physiographic sub-provinces PS and MCS are compared. Nevertheless, based on comparisons between adjacent areas of humid soil, the neighbouring areas with the greatest soil humidity (6 to 9 months) highlight the high turnover among the areas where a higher nestedness correlation was expected (Leitão et al., 2011), indicating a possible underestimation of $\gamma$-diversity in the area with the greatest soil moisture (Pineda and Lobo, 2012). Given these contrasting patterns for observing nestedness and turnover relative to the categories of physiography and soil moisture, respectively, it is clear that the analysis based on overlapping the GAA-2010 maps allows the detection of mesoscale patterns of diversity. This outcome was confirmed by the close correlation between the dissimilarity values and the quantitative dimension of the environmental categories.

The information derived from published data, such as the data from the GAA, is subject to certain constraints, including the coarse scale $(1: 1,000,000)$, the limited extent of field records, and under- or overestimation of species ranges (Serrano, 2006). Consequently, these limitations could increase the inaccuracy of the projections and also produce an over- or underestimation of species richness (Ferrier, 2002; Burgman and Fox, 2003; Baselga et al., 2012; Pineda and Lobo, 2012), but the inclusion of the additive $\beta$-diversity (turnover and nestedness partitioned), contrasted with $\alpha$ and $\gamma$-diversity represented by the environmental units, improves the robustness of the results and decreases the error associated with the scale.

We are aware that the use of coarse-scale data, such as the GAA, in regional-local fine-scale assessment involves problems associated with false presences, because it is assumed that a given species is always present in the analyzed units (e.g. pixel, patch) within the mapped range, while species occurrence is probably restricted to a proportion of these units (Ferrier, 2002). Consequently, some areas in our maps could overestimate amphibian diversity at local (pixels) and regional (focal areas) levels. But these problems were minimized here when we analyzed the $\beta$-diversity (additive formulation), because the environmental layers used represent global categories (climate, physiography, month of soil moisture) and have the same scale as the GAA data. As pointed by Ferrier (2002), when the spatial units of analysis are large enough, there is a high probability for true-presences. Although fine resolution data are included in this study (Aster DEM, Bioclimatic variables, MODIS), there is no conflict as they are used to characterize the environmental categories in bi-dimensional spaces, but not directly used to produce the species distribution maps.

\section{Considerations}

Amphibian conservation in Sinaloa requires additional information. The lack of local or regional studies hampers any attempt by local or international environmental organizations to update the conservation status and adequately support any conservation effort. Additionally, lack of ecological studies limits the development of strategies to maintain viable populations and to identify potential risks, such as chytridiomycosis or landscape changes produced by human development and phenomena related to climate change.

Transformations at the regional level, as those resulting from the expansion of forestry, intensive agriculture and anthropogenic development activity (hydroelectric dams, highways, tourism), are increasing habitat loss in Sinaloa, particularly in the coastal plain (Hardy and McDiarmid, 1969; Berlanga-Robles and Ruiz-Luna, 2011). Future climate change scenarios suggest that mainly the tropical deciduous forest will be impacted, making clear that diverse threats could constrain amphibian species well adapted to local conditions in the west coast of Mexico, a region with high endemism (Hof et al., 2011). To reduce the potential impact on the amphibian populations in this area, it is possible to take advantage on the local physiography and hydrography (including the Presidio, Baluarte and Las Cañas Rivers), preserving areas that could operate as natural corridors, maintaining biological and ecological continuity from the tropical coastal plain to higher regions of the mountains (Webb, 1984). Maintaining the integrity and connectivity of well-preserved patches of natural covers, with natural or artificial wetlands, even with agricultural land maintaining adequate microclimatic, will provide refuges for amphibians (Parris and McCarthy, 1999; Pineda and Halffter, 2004; Suazo-Ortuño et al., 2008). Thus, strategies to preserve specific 
areas, particularly those with high turnover and $\gamma$-values should be included in conservation planning.

Based on the present findings, we conclude that Sinaloa displays environmental conditions that support uncommonly high amphibian species diversity in dry environments, and hence conservation strategies should focus on the maintenance of amphibian distribution areas such as the south-western portion of the state, and sites along the latitudinal turnover gradient between the two principal climate groups. Southern Sinaloa should be considered as a reserve archipelago (Halffter, 2005) in view of the high species turnover detected. Regarding this, new explorations to provide information on the current status of Sinaloa's amphibians must be a priority; identifying the possible relationship of landscape dynamics at the state level with adaptive processes (i.e. to prolonged droughts) that could help conservation of these species.

Finally, despite the limitations, we recognize the importance of global data such as those provided by GAA-2010 database for determining species richness patterns at local and regional scales, particularly when local data are sparse or unavailable. Studies on the diversity and distribution of amphibians in areas with few historical records and with no recent studies can be supported with accessible and user-friendly information derived from distribution range maps at regional scales. Because the diversity and distribution patterns presented in this study have not yet been corroborated in the field, our principal contribution is to provide a starting point for new hypotheses to be tested.

\section{Acknowledgements}

The authors acknowledge the International Union for Conservation of Nature (IUCN) for providing the Global Amphibian assessment database (GAA-2010), and K. Flores, M. Torres and E. Tello for their assistance. JMS was partially supported by fellowships from the CIAD and Academia Mexicana de Ciencias Scientific Summer fellowships. We specially thank the reviewers for their contribution to improve this manuscript.

\section{References}

Allen AP, Brown JH, Gillooly JF. 2002. Global biodiversity, biochemical kinetics, and the energetic-equivalence rule. Science 297: 1545-1548.

Araujo MB. 2002. Biodiversity hotspots and zones of ecological transition. Conservation Biology 16: 1662-1663.

Baselga A. 2010. Partitioning the turnover and nestedness components of beta diversity. Global Ecology and Biogeography 19: 134-143.
Baselga A, Gómez-Rodríguez C, Lobo JM. 2012. Historical legacies in world amphibian diversity revealed by the turnover and nestedness components of beta diversity. PLOS ONE 7: e32341.

Berlanga-Robles CA, Ruiz-Luna A. 2011. Caracterización paisajística de la costa de Sinaloa, México. Pp. 191-216 in: RuizLuna A, Berlanga-Robles CA, Betancourt LM, eds, Avances en Acuicultura y Manejo Ambiental. Mexico: Trillas/Centro de Investigación en Alimentación y Desarrollo A.C.

Burgman MA, Fox JC. 2003. Bias in species range estimates from minimum convex polygons: implications for conservation and options for improved planning. Animal Conservation 6: 19-28.

Burgman MA. Lindenmayer DB, J Elith. 2005. Managing landscapes for conservation under uncertainity. Ecology 86: 2007-2017.

Campbell JA. 1999. Distribution patterns of amphibians in Middle America. Pp. 111-210 in: Duellman WE, ed., Patterns of distribution of amphibians: a global perspective. Baltimore: Johns Hopkins.

Carlson TN. 2007. An overview of the "Triangle Method" for estimating surface evapotranspiration and soil moisture from satellite imagery. Sensors 7: 1612-1629.

Casas G. 1982. Anfibios y reptiles de la costa suroeste del estado de Jalisco, con aspectos sobre su ecología y biogeografía. Mexico: Universidad Nacional Autónoma de México.

Collins JP, Crump ML. 2009. Extinction in Our Times: Global Amphibian Decline. New York: Oxford University.

Currie DJ. 1991. Energy and large-scale patterns of animal and plant-species richness. American Naturalist 137: 27-49.

Daszak P, Cunningham AA, Hyatt AD. 2003. Infectious disease and amphibian population declines. Diversity and Distributions 9: 141-150.

Duellman WE. 1988. Patterns of species diversity in anuran amphibians in the American tropics. Annals of the Missouri Botanical Garden 75: 79-104.

Duellman WE. 1999. Global distribution of amphibians: patterns, conservation and future challenges. Pp. 1-30 in: Duellman WE, ed., Patterns of distribution of amphibians: a global perspective. Baltimore: Johns Hopkins.

Duellman WE, Thomas R. 1996. Anuran amphibians from a seasonally dry forest in southeastern Peru and comparisons of the anurans among sites in the Upper Amazon Basin. Occasional Papers of the Museum of Natural History University of Kansas 180: 1-34.

Eastman JR. 2012. IDRISI Selva. Guide to GIS and Image Processsing. Massachusetts: Clark University.

Elith J, Leathwick J. 2009. Conservation prioritization using species distribution modeling. Pp. 70-93 in: Moilanen A, Wilson KA, Possingham HP, Spatial conservation prioritization: quantitative methods and computational tools. Oxford University Press.

Ferrier S. 2002. Mapping spatial pattern in biodiversity for regional conservation planning: where to from here? Systematic Biology 51: 331-363.

Fisher MC, Garner TW, Walker SF. 2009 Global emergence of Batrachochytrium dendrobatidis and amphibian chytridiomycosis in space, time, and host. Annual Review of Microbiology 63: 291-310.

García ME. 1987. Modificaciones al Sistema de Clasificación Climática de Köppen. Mexico: Universidad Nacional Autónoma de México. 
García A. 2006. Using ecological niche modeling to identify diversity hotspots for the herpetofauna of Pacific lowlands and adjacent interior valleys of Mexico. Biological Conservation 130: 25-46.

Guisan A, Hofer U. 2003. Predicting reptile distributions at the mesoscale: relation to climate and topography. Journal of Biogeography 30: 1233-1243.

Halffter G. 1998. A strategy for measuring landscape biodiversity. Biology International 36: 3-17.

Halffter G. 2005. Towards a culture of biodiversity conservation. Acta Zoológica Mexicana 21: 133-153.

Hardy LM, McDiarmid RW. 1969. The amphibians and reptiles of Sinaloa, Mexico. University of Kansas Publications 18: 39-252.

Hayek LC, McDiarmid RW. 1994. GIS and remote sensing techniques. Pp. 166-171 in: Heyer WR, Donnelly MA, McDiarmid RW, Hayek LC, Foster MS, eds, Measuring and monitoring biological diversity standard methods for amphibians. Washington, DC: Smithsonian Inst. Press.

Hoffman M, Hilton-Taylor C, Angulo A, et al. 2010. The impact of conservation on the status of the world's vertebrates. Science 300: 1503-1509.

Hof C, Araújo MR, Jetz W, Rahbek C. 2011. Additive threats from pathogens, climate and land-use change for global amphibian diversity. Nature 480: 516-521.

INEGI. 1995. Estudio Hidrológico del Estado de Sinaloa. México: Instituto Nacional de Estadística Geografía e Informática.

IUCN. 2010. Global Amphibian Assessment. International Union for Conservation of Nature: http://www.iucnredlist.org. [accessed 12 Dec. 2012]

James FC, McCulloch CE. 1990. Multivariate analysis in ecology and systematics: Panacea or Pandora's Box? Annual Review of Ecology and Systematics 21: 129-166.

Kohlmann B, Wilkinson J. 2003. Fronteras biogeográficas: coincidencia entre factores climáticos, topográficos, geológicos e históricos. Pp. 221-226 in: Morrone JJ, Llorente Bousquets J, eds, Una perspectiva latinoamericana de la biogeografía. México: CONABIO-UNAM.

Legendre P, Fortin MJ. 1989. Spatial patterns and ecological analysis. Vegetatio 80: 107-138.

Legendre P, Fortin MJ. 2010. Comparison of the Mantel test and alternative approaches for detecting complex multivariate relationships in the spatial analysis of genetic data. Molecular Ecology Resources 10: 831-844.

Leitão PJ, Moreira M, Osborne PE. 2011. Effects of geographical data sampling bias on habitat models of species distributions: a case study with steppe birds in southern Portugal. International Journal of Geographical Information Science 25: 439-454.

Manly BFJ. 1986. Randomization and regression methods for testing for associations with geographical, environmental and biological distances between populations. Population Ecology 28: 201-218.

McDiarmid RW, Copp JF, Breedlove DE. 1976. Notes on the herpetofauna of Western Mexico: new records from Sinaloa and the Tres Marías Islands. Science Natural History $M u$ seum of Los Angeles County 275: 1-17.

Munguía M, Rahbek C, Rangel TF, Diniz-Filho JAF, Araújo MB. 2012. Equilibrium of Global Amphibian Species Distributions with Climate. PLOS ONE 7: e34420.
Morrone JJ. 2005. Hacia una síntesis biogeográfica de México. Revista Mexicana de Biodiversidad 76: 207-252.

Norma Oficial Mexicana NOM-059-SEMARNAT-2001. 2010. Protección ambiental-Especies nativas de México de flora y fauna silvestres-Categorías de riesgo y especificaciones para su inclusión, exclusión o cambio-Lista de especies en riesgo. Mexico: Diario Oficial 12-30-2010.

Ochoa-Ochoa L, Urbina-Cardona JN, Vázquez LB, FloresVillela O, Bezaury-Creel J. 2009. The effects of governmental protected areas and social initiatives for land protection on the conservation of Mexican amphibians. PLOS ONE 4: e6878.

Parris KM, McCarthy MA. 1999. What influences the structure of frog assemblages at forest streams? Australian Journal of Ecology 245: 495-502.

Pineda E, Halffter G. 2004. Species diversity and habitat fragmentation: frogs in a tropical montane landscape in México. Biological Conservation 117: 499-508.

Pineda E, Lobo JM. 2012. The performance of range maps and species distribution models representing the geographic variation of species richness at different resolutions. Global Ecology and Biogeography 21: 935-944.

Savage JM. 1982. The enigma of the Central American herpetofauna: dispersals or vicariance? Annals of the Missouri Botanical Garden 69: 464-547.

Seimon TA, Seimon A, Daszak P, Halloy SRP, Schloegel LM, Aguilar CA, Sowell P, Hyatt AD, Konecky B, Simmons J. 2006. Upward range extension of Andean anurans and chytridiomycosis to extreme elevations in response to tropical deglaciation. Global Change Biology 12: 1-12.

Serrano JM. 2006. Análisis especial de la distribución de los anfibios en Sinaloa, México. México: Universidad Autónoma Metropolitana.

Soberon J. 2010. Niche and area of distribution modeling: a population ecology perspective. Ecography 33: 159-167.

Soberon J, Nakamura M. 2009. Niches and distributional areas: concepts, methods, and assumptions. Proceedings of the National Academy of Sciences of the United States of America 106: 19644-19650.

Sokal RR, Rohlf FJ. 2001. Biometry: The Principles and practices of statistics in biological research. New York: Freeman

Spector S. 2002. Biogeographic crossroads as priority areas for biodiversity conservation. Conservation Biology 16: 14801487.

Stuart SN, Chanson JS, Cox NA, et al. 2004. Status and trends of amphibian declines and extinctions worldwide. Science 306: 1783-1786.

Suazo-Ortuño I, Alvarado-Díaz J, Martínez-Ramos M. 2008. Effects of conversion of dry tropical forest to agricultural mosaic on herpetofaunal assemblages. Conservation Biology 22: 362-374.

Urbina-Cardona JN, Flores-Villela O. 2010. Ecological niche modeling and prioritization of conservation-area networks for Mexican herpetofauna. Conservation Biology 24: 10311041.

Webb RG. 1984. Herpetogeography in the Mazatlan-Durango region of the Sierra Madre Occidental, Mexico. Pp. 217-241 in: Seigel RA, Hunt LE, Knight JL, Malaret L, Zuschlag NL, eds, Vertebrate ecology and systematic. Kansas: University of Kansas Special Publication. 
Williams PH. 1996. Mapping variations in the strength and breadth of biogeographic transition zones using species turnover. Proceedings of the Royal Society of London B 263: 579-588.

Young BE, Stuart SN, Chanson JS, Cox NA, Boucher TM. 2004. Disappearing Jewels: The Status of New World Amphibians. Arlington: Nature Serve.

Received: 6 November 2013

Revised and accepted: 7 April 2014

Published online: 2 May 2014

Editor: B.M. Wielstra 